\title{
Model Pembelajaran Studysaster Dalam Upaya Meningkatkan Imunitas pada Pandemi Covid-19
}

\author{
Erna Widyasari \\ SMP AI Azhar Syifa Budi Solo \\ supmatahari@yahoo.com
}

\section{Article History}

accepted 01/12/2020

approved 01/01/2021

published 01/03/2021

\begin{abstract}
The Covid-19 outbreak has suddenly changed Indonesia's education system. Learning that was originally face-to-face turned online. Students study at home and unfinished material is delivered using information technology and adapted for Covid-19 prevention education. One learning model that was suitable during the Covid-19 pandemic was a study master. Through studysaster learning, teachers can contribute significantly to the prevention of Covid-19 and create healthy school members free from the threat of Covid-19. One teacher will educate students, then each student will educate the family and the surrounding community, as well as the wider community through their social media. One of the projects in the study center for the prevention of Covid-19 is the manufacture of drinks to increase body immunity according to the classification material. Identification of beverage ingredients using the PictureThis application and learning media using the GSuite platform.
\end{abstract}

Keywords: Studysaster, Covid-19

\begin{abstract}
Abstrak
Wabah Covid-19 telah mengubah tatanan pendidikan Indonesia secara mendadak. Pembelajaran yang semula berupa tatap muka berubah menjadi daring/ jarak jauh. Siswa belajar di rumah dan materi yang belum terselesaikan disampaikan dengan memanfaatkan teknologi informasi serta disesuaikan untuk edukasi pencegahan Covid-19. Salah satu model pembelajaran yang sesuai pada masa pandemi Covid-19 adalah studysaster. Melalui pembelajaran studysaster guru dapat berkontribusi nyata yang berdampak luas dalam pencegahan Covid-19 serta menciptakan warga sekolah yang sehat dan terbebas dari ancaman Covid-19. Satu guru akan mengedukasi siswa, selanjutnya setiap siswa akan mengedukasi keluarga dan masyarakat sekitarnya, juga masyarakat luas melalui media sosial yang mereka miliki. Salah satu proyek pada studysaster untuk pencegahan Covid-19 adalah pembuatan minuman untuk meningkatkan imunitas tubuh yang disesuaikan dengan materi klasifikasi. Identifikasi bahan-bahan minuman menggunakan aplikasi PictureThis dan media pembelajaran menggunakan platform GSuite.
\end{abstract}

Kata kunci: Studysaster, Covid-19

Social, Humanities, and Education Studies (SHEs): Conference Series https://jurnal.uns.ac.id/shes

p-ISSN 2620-9284

e-ISSN 2620-9292 


\section{PENDAHULUAN}

Indonesia adalah salah satu negara di dunia yang terkena wabah Covid-19. Wabah ini disebabkan virus corona. Virus corona atau severe acute respiratory syndrome coronavirus 2 (SARS-CoV-2) adalah virus yang menyerang sistem pernapasan. Penyakit karena infeksi virus ini disebut Covid-19. Perubahan terjadi di dunia pendidikan akibat wabah tersebut. Sekolah diliburkan, pembelajaran yang semula berupa tatap muka diubah menjadi pembelajaran jarak jauh/ daring. Langkah ini diambil oleh pemerintah guna menekan penyebaran Covid-19. Menurut data yang dirilis Gugus Tugas Percepatan Penanganan COVID-19 Republik Indonesia melalui laman alodokter.com, jumlah kasus terkonfirmasi positif hingga 26 Mei 2020 adalah 22.750 orang dengan jumlah kematian 1.391 orang. Penyakit ini dapat menular dengan mudah tanpa mengenal usia. Oleh karena itu, diperlukan langkah untuk mencegah terjangkit Covid-19, salah satunya adalah membuat minuman penambah imunitas tubuh.

Pembuatan minuman penambah imunitas tubuh memang tidak dapat membunuh virus corona, namun setidaknya mampu menambah kekebalan tubuh dan menciptakan masyarakat Indonesia yang sehat dan terbebas dari wabah Covid-19. Guru dapat mengambil peran edukasi tersebut melalui model pembelajaran studysaster. Surat Edaran Menteri no 4 Tahun 2020 menjelaskan tidak ada tuntutan untuk menuntaskan kurikulum, namun materi yang belum tersampaikan karena sekolah diliburkan dapat dimasukkan ke dalam model pembelajaran studysaster ini. Guru membimbing siswa melalui pembelajaran daring untuk melakukan langkah pencegahan bencana dan sekaligus menerapkan dalam kehidupan sehari-hari demi terciptanya masyarakat Indonesia yang sehat. Dari latar belakang tersebut dapat dirumuskan masalah sebagai berikut:

1. Apakah model pembelajaran studysaster dengan materi klasifikasi dapat diterapkan pada siswa ketika pembelajaran daring?

2. Apakah pembuatan minuman penambah imunitas dapat mengedukasi siswa dalam upaya pencegahan Covid-19 dan tetap menjaga kesehatan?

Model pembelajaran studysaster adalah model pembelajaran yang bertujuan mengedukasi siswa tentang bencana (dalam hal ini Covid-19) dan mampu menghasilkan produk. Nama studysaster diambil dari akronim "study" yang dalam bahasa Indonesia berarti belajar dan "disaster" yang berarti bencana (Fitroni, 2020). Lebih lanjut Fitroni menjelaskan bahwa model pembelajaran studysaster dapat didefinisikan sebagai sebuah tahapan pembelajaran yang sistematis dalam mengorganisasikan pengalaman belajar, untuk memaksimalkan pengintegrasian pendidikan kebencanaan. Model ini mempunyai enam langkah pembelajaran yaitu Identification/ identifikasi; Search/ mencari; Plan/ merencanakan; Create/ mencipta; Share/ membagikan dan Practise/ mempraktikkan

Adapun tujuan dari pembelajaran ini adalah:

1. Menerapkan materi klasifikasi dalam kehidupan sehari-hari melalui model pembelajaran studysaster.

2. Mengedukasi siswa untuk pencegahan Covid-19 dan tetap menjaga kesehatan melalui pembuatan minuman penambah imunitas.

Manfaat dari pembelajaran ini adalah:

1. Siswa dapat mempelajari dan memahami materi klasifikasi yang dipadukan dalam model pembelajaran studysaster.

2. Siswa dapat menerapkan pola sehat dalam kehidupan sehari-hari dan turut berperan mengedukasi keluarga, teman, dan masyarakat sekitar.

3. Terciptanya masyarakat yang sehat melalui edukasi pembuatan minuman penambah imunitas. 
HASIL DAN PEMBAHASAN

Pemberian tugas dilaksanakan melalui media GSuite. Siswa telah memiliki akun sekolah pada GSuite dengan domain smpasbsolo.sch.id. Diskusi dilaksanakan secara daring melalui GMeet. Tugas diberikan setelah selesai berdiskusi, kemudian siswa diminta untuk membaca instruksi, memahami, mengerjakan, dan melaporkan tugas pada tautan GForm yang telah disediakan pada tautan https://forms.gle/pA97ryTbo7WXMzHJ9. Tugas yang diberikan berupa penelusuran tentang resep minuman penambah imunitas tubuh, nama ilmiah dari bahan-bahan alami pada resep tersebut (materi klasifikasi), praktik untuk membuat minuman tersebut, dan edukasi pada orang-orang disekitar.

Pada pembelajaran tatap muka siswa telah mempelajari materi klasifikasi terutama untuk penamaan ilmiah tumbuhan tertentu dengan menggunakan aplikasi PictureThis untuk identifikasi tumbuhan dan situs plantamor.com untuk sistematika klasifikasinya. Namun, dalam pembelajaran studysaster ini tidak sampai pada sistematika klasifikasi, hanya sampai pada penamaan ilmiah bahan-bahan yang akan digunakan siswa untuk membuat minuman penambah imunitas tubuh.
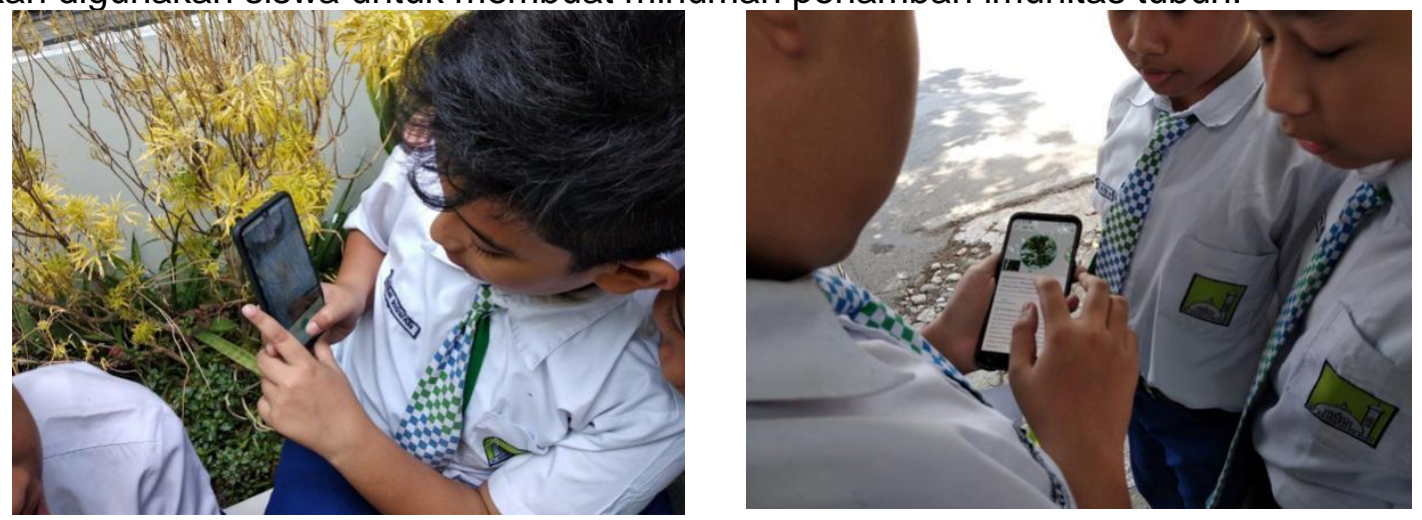

\section{Gambar 1. Identifikasi Tumbuhan Menggunakan Aplikasi PictureThis}

Model pembelajaran yang digunakan adalah studysaster. Model pembelajaran ini mengharapkan guru mempunyai peran strategis dalam melakukan edukasi pencegahan dan menekan penyebaran Covid-19. Model ini mempunyai enam langkah pembelajaran sebagai berikut:

1. Identification/ identifikasi

Pada langkah mengidentifikasi, siswa bersama dengan guru mempelajari dan berdiskusi tentang definisi maupun jenis-jenis bencana yang ada dan penyebab terjadinya bencana, salah satunya adalah bencana Covid19. Diskusi dilaksanakan melalui video conference melalui GMeet. Dari diskusi tersebut siswa dengan bimbingan guru mampu melakukan identifikasi resiko bencana kesehatan Covid-19 pada dirinya sendiri, maupun orang-orang di lingkungan tempat tinggalnya. Salah satu pencegahan agar tidak tertular Covid19 dan tubuh tetap sehat adalah membuat dan mengonsumsi minuman penambah imunitas tubuh. 
SHEs: Conference Series 4 (2) (2021) 32- 37

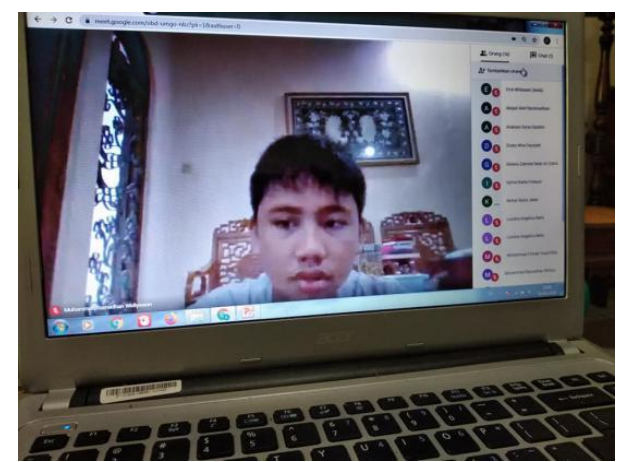

Gambar 2. Diskusi melalui GMeet

2. Search/ mencari

Siswa diminta untuk mengidentifikasi dan mencari resep minuman penambah stamina tubuh melalui internet, mencari nama ilmiah dari bahan-bahan yang mereka pergunakan melalui aplikasi PictureThis.

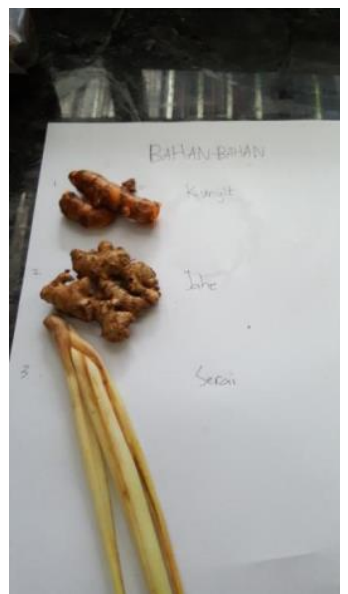

\section{Gambar 3. Identifikasi Nama IImiah}

3. Plan/ merencanakan

Siswa melakukan proses mencari referensi maka akan muncul ide/imajinasi awal untuk membuat konsep dari minuman yang akan mereka buat. Nama ilmiah dari bahan-bahan alami yang mereka buat dituliskan pada selembar kertas berikut resep pembuatannya sebagai acuan dalam membuat karya pembelajaran.

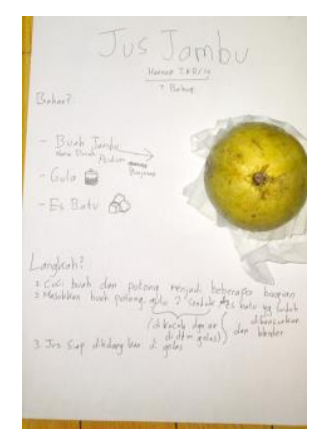

\section{Gambar 4. Resep Minuman Penambah Imunitas Tubuh}

4. Create/ mencipta

Setelah menemukan ide/pesan dan rencana karya yang akan dikerjakan, maka siswa mulai membuat rancangan tersebut. Minuman yang 
dibuat oleh siswa bervariasi mulai dari jus, minuman empon-empon, hingga jamu tradisional.

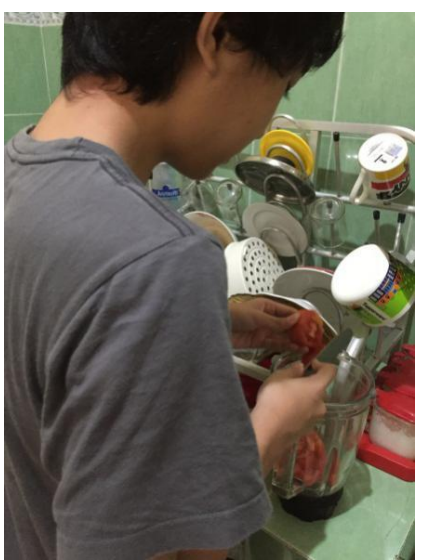

Gambar 5. Proses Pembuatan Minuman

5. Share/ membagikan

Langkah share/membagikan merupakan kegiatan untuk mengedukasi orang lain secara luas. Siswa mendiseminasikan karyanya secara langsung kepada orang-orang di rumahnya maupun masyarakat disekitarnya sehingga ikut melakukan pencegahan Covid-19 dan menjadikan masyarakat sehat terbebas dari Covid-19.

6. Practise/ mempraktikkan

Karya pembelajaran tentang bencana Covid-19 tersebut wajib untuk dipraktikkan dalam kehidupan sehari-hari agar yang mereka lakukan tidak hanya pada tataran konseptual saja.

Produk yang dihasilkan pada pembelajaran ini adalah minuman penambah imunitas tubuh yang mereka buat dan konsumsi sendiri. Sekaligus mengajak keluarga dan masyarakat sekitar rumah siswa untuk turut mengonsumsinya guna mencegah penularan Covid-19 sehingga tercipta masyarakat yang sehat dan terbebas dari ancaman Covid-19.

Pada tanggal 1 - 6 Juni 2020 seluruh siswa dapat melaksanakan Penilaian Akhir Tahun dan tidak ada siswa yang absen karena sakit. Meskipun sebagian besar mata pelajaran menggunakan GForm sebagai media untuk Penilaian Akhir Tahun, namun mata pelajaran tahsin tahfidz dan Al Quran'an hadits dilaksanakan melalui video conference (Gmeet) sehingga dapat membuktikan keseluruhan siswa dalam keadaan sehat.

Tugas pembuatan minuman ini paling lambat dikumpulkan pada tanggal 29 Mei 2020. Dari 80 siswa kelas 7 yang melakukan pembelajaran studysaster ini, hanya 54 siswa yang mengumpulkan tugas pada tanggal tersebut. Beberapa kendala mungkin dihadapi oleh siswa yang tidak mengumpulkan tugas antara lain:

1. tidak semua siswa memiliki ponsel ataupun laptop

2. sinyal internet yang berbeda

3. pengawasan orang tua yang kurang memadai

4. pengaturan waktu oleh siswa antara bermain dengan belajar yang kurang

5. faktor jenuh dan kebosanan siswa terhadap tugas-tugas yang ada

6. belum memahami cara pengumpulan tugas.

Oleh karena itu, dilakukan penagihan tugas bagi siswa yang belum mengumpulkan pada tanggal tersebut. Siswa yang terkendala tidak memiliki ponsel atau laptop datang ke sekolah untuk melaksanakan tugas. Sehingga pada tanggal 31 Mei 2020 semua siswa dapat mengumpulkan tugas. 
SHEs: Conference Series 4 (2) (2021) 32- 37

Rencana tindak lanjut dari pembelajaran ini adalah edukasi kepada masyarakat luas melalui media sosial yang dimiliki oleh setiap siswa. Walaupun belum ada tugas untuk membuat video maupun pamflet, beberapa siswa sudah berinisiatif untuk membuatnya.

\section{SIMPULAN}

Simpulan dari best practise ini adalah:

1. model pembelajaran studysaster secara daring dengan materi klasifikasi dapat diterapkan pada siswa melalui identifikasi bahan-bahan alami minuman penambah imunitas.

2. pembuatan minuman penambah imunitas dapat mengedukasi siswa dalam upaya pencegahan Covid-19 dan tetap menjaga kesehatan sehingga tercipta masyarakat yang sehat pada umumnya.

Model pembelajaran studysaster ini masih belum banyak dipelajari oleh guru sebagai fasilitator dalam pembelajaran. Model pembelajaran ini diharapkan dapat diterapkan secara luas sebagai salah satu strategi pencegahan dan penanganan bencana sekaligus langkah menjaga kesehatan dan keselamatan siswa, guru, warga sekolah, dan masyarakat umum.

\section{DAFTAR PUSTAKA}

Ayu, W. 2020. Tim FK UI dan IPB Temukan Kandidat Pencegah Virus Corona. https://www.ui.ac.id/tim-fk-ui-dan-ipb-temukan-kandidat-pencegah-virus-corona/ (Diunduh 28 Mei 2020)

Dame, M. 2020. Virus Corona (Covid-19). https://www.alodokter.com/virus-corona (Diunduh 28 Mei 2020)

Fitroni, Z. 2020. Studysaster: Kontribusi Guru Cegah Covid-19. https://guruberbagi.kemdikbud.go.id/artikel/studysaster-kontribusi-guru-cegahcovid-19/ (Diunduh 8 Mei 2020)

Surat Edaran Menteri Nomor 4 Tahun 2020 